\title{
Inheritance of Pathogenicity in Crosses of Pyricularia Isolates from Weeping Lovegrass and Finger Millet
}

\author{
Hiroshi YAEGASHI* \\ 八重樫博志：ウィピングラブグラスとシコクビエから分離した \\ いむち病菌の交配による病原性の遣伝
}

\begin{abstract}
Heterothallic isolates of Pyricularia pathogenic on different hosts were used to demonstrate experimentally the genetic segregation of factors for pathogenicity and mating type through the perfect stage. The pathogenicity of 325 monoascosporic progeny from the crosses of Pyricularia isolates from weeping lovegrass and finger millet to the original hosts segregated $136: 127: 26: 36$; pathogenic to weeping lovegrass alone, finger millet alone, both weeping lovegrass and finger millet, and nonpathogenic to both hosts, respectively. Based upon a 1:1 segregation, the pathogenicity to weeping lovegrass or finger millet seems to be conditioned by a single gene. The results suggest that factors for pathogenicity to two hosts are conditioned by different genes located at different loci on homologous chromosomes. Mating type was inherited independently of pathogenicity. Pathogenicity and mating type were determined for eight ascospores from a single ascus. Judging from the ascospore analysis and the previous cytological study of the ascus, it seems that factors for pathogenicity and mating type are conditioned by chromosomal genes.
\end{abstract}

(Received September 13, 1978)

\section{Introduction}

One of the most important means of controlling rice blast disease is the development of resistant varieties. The trouble is, however, that the newly developed resistant varieties often give way to blast fungi after a few years of commercial production. This suggests that a new approach is needed to maintain resistance to blast. It is generally considered that genetic studies of the pathogen, as well as of the host, may provide useful information for developing varieties with lasting resistance. In Pyricularia species, however, the lack of the sexual stage has for a long time made genetic studies of this fungus difficult. Actually only limited information is available on the mechanism of the pathogenic variability $1,2,3,4,8,9,10,11,18)$, compared with many reports on the variation of this organism. Although these reports indicated that the pathogenic variation could be caused by mutation, heterokaryosis or parasexual recombination in the asexual stage, there are still many vague points as to how new types of pathogens are developed. On the other hand, some workers succeeded recently in producing the perfect stage of blast fungi in culture $5,6,7,12,13,14,15)$ and provided a good basis for genetic study. Since genetic research of pathogenicity through the sexual stage might be helpful to work out the con-

* Tohoku National Agricultural Experiment Station, Omagari, Akita 014-01, Japan 農林水産省 東北農業試験場 
troversial problems, studies were made on the pathogenic segregation of ascospore progeny obtained from crosses of blast fungi having different pathogenic factors. Results on the inheritance of factors for pathogenicity and mating type are reported herein.

\section{Materials and Methods}

Six monoconidial isolates of Pyricularia species from weeping lovegrass [Eragrostis curvula (Schrad.) Nees] and finger millet [Eleusine coracana (L.) Gaertn.] were used as parental isolates for obtaining ascospore progeny. These isolates are morphologically indistinguishable, but are easily differentiated by their pathogenicity to selected hosts as shown in Table 1. The heterothallic nature and pathogenicity of

Table 1. Host source, mating type, and pathogenicity of Pyricularia isolates used

\begin{tabular}{l|l|c|c|c}
\hline \multirow{2}{*}{ Isolate } & \multicolumn{1}{|c|}{ Host source } & Mating type & Pathogenicity to \\
\cline { 3 - 4 } & & & Weeping lovegrass & Finger millet \\
\hline 09 & Weeping lovegrass & $a$ & + & - \\
K76-79 & Weeping Lovegrass & $a$ & + & + \\
T75-26 & Finger millet & $A$ & \pm & + \\
T75-29 & Finger millet & $a$ & \pm & + \\
CG-FMa & Mutant from goose grass isolate & $a$ & \pm & + \\
T77-34 & Finger millet & $a$ & \pm \\
\hline
\end{tabular}

$*+=$ pathogenic $;-=$ nonpathogenic; $\pm=$ tiny lesions produced often.

** All of these parental isolates are, in addition to the above hosts, pathogenic to Italian ryegrass, tall fesque, sweet vernal grass, and reed canary grass, and nonpathogenic to rice and crabgrass.

the isolates used were stable. Techniques for mating the compatible parental isolates were previously described in detail ${ }^{16)}$. While the eight ascospores of an ascus were obtained in serial order for the ascospore analysis, most of the single ascospores were isolated at random and stocked on tube slants of potato-sucrose agar. These ascosporic isolates were mated to the fertile tester lines to determine their mating types. Each isolate was increased on oat meal agar and then used to prepare the spore suspension for inoculation. Since qualitative differences in host reaction to the pathogen were evaluated, no special effort was made to standardize the spore density. Two hosts, weeping lovegrass and finger millet, were mainly employed for identifying the pathogenic segregation of the ascosporic isolates, and other hosts; Italian ryegrass (Lolium multiflorum Lam.), tall fesque (Festuca elatior L.), sweet vernal grass (Anthoxanthum odoratum L.), and reed canary grass (Phalaris arundinacea L.); were added as test plants for some isolates. The test plants grown in a greenhouse for 3-4 weeks were inoculated with spore suspensions by spraying and kept in a moist chamber for $16-20$ hours at $26-28 \mathrm{C}$, and then transfered to the greenhouse. Although there were some differences among host species in leaf stage and height of seedlings when inoculated, host plants of each species were comparable in each infection trial. The reactions of host plants to each ascosporic isolate were evaluated 6-7 days after inoculation, and confirmed at least twice. 


\section{Results}

Ascosporic isolates from crosses between weeping lovegrass isolates and finger millet isolates were classified for reaction on these two hosts using the standard shown in Figure 1. The presumed genotype inducing each type of reaction is also shown

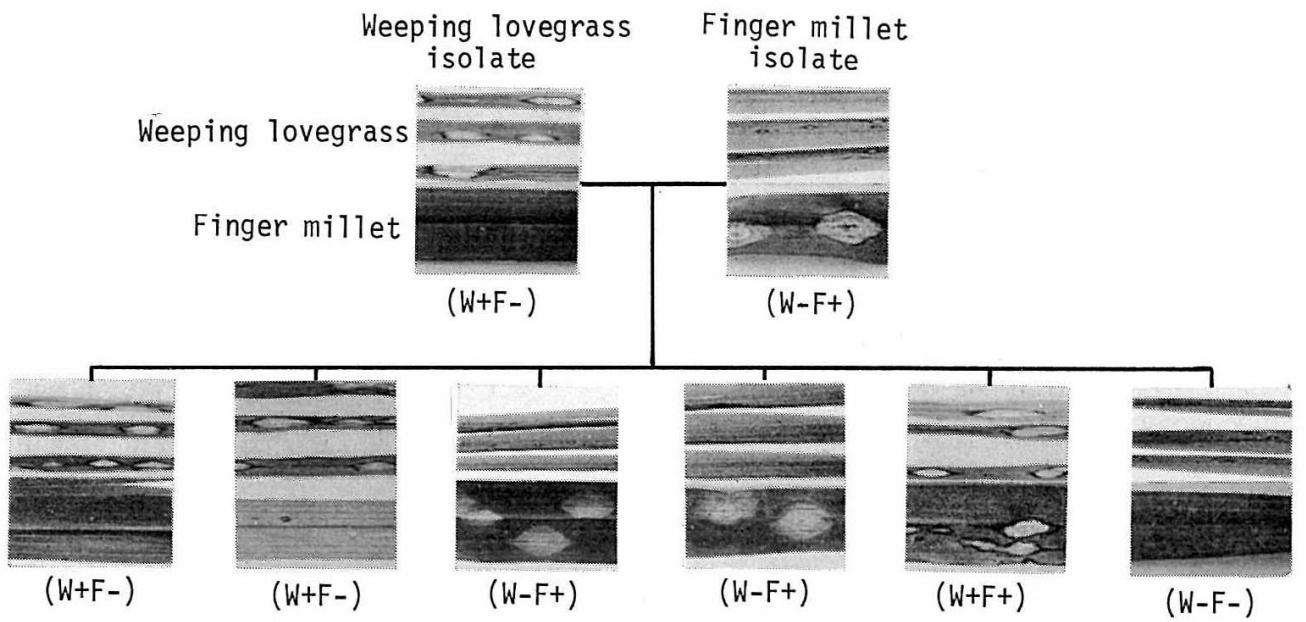

Fig. 1. Pathogenic reaction of parental and ascosporic isolates of Pyricularia $s p p$. to the two differential hosts

* The presumed genotypes are indicated in parenthesis. The presumed genotypes for pathogenicity to Italian ryegrass, tall fesque, sweet vernal grass, reed canary grass, rice, and crabgrass are eliminated to simplify the indication.

in this figure. The test isolate was considered to be pathogenic if large grayish lesions or grayish eyespots with brown margins were induced on host plants, whereas if no symptoms or brown pinpoint lesions were incited, the isolate was considered to be nonpathogenic. Occasionally quite small eyespots with brown necrotic areas were observed on the test hosts, but these tiny lesions were regarded as resistant reactions because of the remarkable difference between the tiny lesions and the susceptible lesions. Another characteristic reaction was observed on finger millet when inoculated with ascosporic isolates pathogenic to both weeping lovegrass and finger millet. The susceptible lesions on finger millet were usually well-defined by brown margins and relatively smaller than those of the parent isolate. On the other hand, the ascospore isolates which were considered nonpathogenic to weeping lovegrass and finger millet did not induce susceptible type lesion on these two hosts despite the abundunce of spores in the inoculum. However, on some other hosts (Italian ryegrass, tall fesque, sweet vernal grass, and reed canary grass) these isolates incited typical susceptible leaf reactions. It suggests that it is due to the modifying factors or a partial deficit of factors conditioning pathogenicity.

Results of segregation for pathogenicity on the two differential hosts are summerized in Tables 2, 3, and 4. Based upon a 1:1 segregation, pathogenicity seems to be conditioned by a single gene. In crosses between isolates having the same pathogenicity to the given hosts, no segregation occurred for pathogenicity but only for mating type a 1:1 segregation was observed in the ascospore progeny. However, crosses between weeping lovegrass isolate and finger millet isolate yielded progeny of nonparental types as well as of parental types, $i$. e., the 325 monoascosporic isolates 
Table 2. Inheritance of pathogenicity to weeping lovegrass and finger millet in Pyricularia $s p p$. (1)

\begin{tabular}{c|c|c}
\hline \multirow{2}{*}{ Cross } & $\begin{array}{c}\text { Pathogenic to weeping lovegrass } \\
\text { Nonpathogenic to finger millet } \\
(W+F-)\end{array}$ & $\begin{array}{c}\text { Nonpathogenic to weeping lovegrass } \\
\text { Pathogenic to finger millet } \\
(W-F+)\end{array}$ \\
\hline $\begin{array}{c}909 \times \times(\mathrm{K} 76-79 \\
(W+F-)(W+F-)\end{array}$ & 25 & 0 \\
$\begin{array}{c}\mathrm{T} 75-26 \times \mathrm{T} 75-29 \\
(W-F+)(W-F+)\end{array}$ & 0 & 36 \\
\end{tabular}

* $(W+F-)$ : Pathogenic to weeping lovegrass and nonpathogenic to finger millet. $(W-F+)$ : nonpathogenic to weeping lovegrass and pathogenic to finger millet.

** Figures in parenthesis are mating type distribution $(A: a)$.

Table 3. Inheritance of pathogenicity to weeping lovegrass and finger millet in Pyricularia spp. (2)

\begin{tabular}{|c|c|c|c|c|c|c|c|}
\hline \multirow{2}{*}{\multicolumn{3}{|c|}{$\begin{array}{c}\text { Cross } \\
(W+F-) \times \underset{(W-F+)}{(W-F+}\end{array}$}} & \multirow{2}{*}{$\begin{array}{c}\text { Number of } \\
\text { ascospores } \\
\text { isolated }\end{array}$} & \multicolumn{2}{|c|}{ Pathogenic to weeping lovegrass } & \multicolumn{2}{|c|}{$\begin{array}{l}\text { Nonpathogenic to weeping } \\
\text { lovegrass }\end{array}$} \\
\hline & & & & $\begin{array}{l}\text { Pathogenic to } \\
\text { finger millet } \\
\quad(W+F+)\end{array}$ & $\left|\begin{array}{c}\text { Nonpathogenic } \\
\text { to finger millet } \\
\quad(W+F-)\end{array}\right|$ & $\begin{array}{l}\text { Pathogenic to } \\
\text { finger millet } \\
\quad(W-F+)\end{array}$ & $\begin{array}{l}\text { Nonpathogenic } \\
\text { to finger millet } \\
\quad(W-F-)\end{array}$ \\
\hline \multirow[t]{5}{*}{909} & $x$ & T75-29 & & & & & \\
\hline & 1 & & 62 & 5 & 19 & 37 & 1 \\
\hline & 2 & & $18^{*}$ & 3 & 8 & 6 & 1 \\
\hline & 3 & & $47 *$ & 3 & 22 & 13 & 9 \\
\hline & 4 & & $23 *$ & 1 & 10 & 7 & 5 \\
\hline 909 & $x$ & CG-FMa & 39 & 0 & 17 & 17 & 5 \\
\hline 909 & $x$ & $\mathrm{~T} 77-34$ & 136 & 14 & 60 & 47 & 15 \\
\hline \multicolumn{3}{|c|}{ [Total] } & [325] & {$[26]$} & {$[136]$} & {$[127]$} & {$[36]$} \\
\hline \multicolumn{3}{|c|}{$(A: a)$} & $(155: 170)$ & $(8: 18)$ & $(70: 66)$ & $(58: 69)$ & $(19: 17)$ \\
\hline
\end{tabular}

* Ascospores from a single perithecium.

Table 4. Segregation for pathogenicity in ascospore progeny of Pyricularia spp. to the two differential hosts

\begin{tabular}{|c|c|c|c|c|c|}
\hline \multirow{2}{*}{ Host } & \multicolumn{2}{|c|}{ No. of ascospore progeny } & \multirow{2}{*}{\multicolumn{2}{|c|}{$\frac{\text { Expected ratio }}{\text { Pathogenic Nonpathogenic }}$}} & \multirow{2}{*}{$\begin{array}{l}\mathrm{P} \text { value } \\
\text { from } \\
\mathrm{X}^{2} \text { test }\end{array}$} \\
\hline & Pathogenic & Nonpathogenic & & & \\
\hline Weeping lovegrass & 162 & 163 & 1 & 1 & $>0.9$ \\
\hline Finger millet & 153 & 172 & 1 & 1 & $0.5-0.3$ \\
\hline
\end{tabular}

from crosses the two host specific isolates segregated 136:127:26:36 for pathogenicity to weeping lovegrass alone, finger millet alone, both weeping lovegrass and finger millet, and nonpathogenicity to both hosts. The excess of parental phenotypes $(81 \%)$ suggests that the genes are not independent. Furthermore, the presence of recombinant types indicates that the two genes are at different loci. The two mating types were distributed almost evenly in each phenotypic group for pathogenicity, which means that compatibility was inherited independently of pathogenicity.

To get information relating to segregation for pathogenicity and mating type in indivisual ascus, several attempts were made to isolate the eight ascospores in serial order using a micro-manipulator. 
Table 5. Ascospore analysis for mating type and pathogenicity in cross of Pyricularia isolates from weeping lovegrass and finger millet

\begin{tabular}{c|c|c|c}
\hline \hline \multirow{2}{*}{ Ascospore } & Mating type & \multicolumn{2}{|c}{ Pathogenicity to } \\
& $\begin{array}{c}\text { Weeping } \\
\text { lovegrass }\end{array}$ & $\begin{array}{c}\text { Finger } \\
\text { millet }\end{array}$ \\
\hline 1 & $a$ & + & - \\
2 & $a$ & + & - \\
3 & $A$ & + & - \\
4 & $A$ & + & - \\
5 & $a$ & \pm & + \\
6 & $A$ & \pm & + \\
7 & $a$ & \pm & + \\
8 & $A$ & \pm
\end{tabular}

* $+=$ pathogenic ; $-=$ nonpathogenic ; $\pm=$ tiny lesions produced.

The biseriate arrangement of the ascospores made it difficult to determine precisely the serial order in which the ascospores were formed. Data from one ascus is shown in Table 5. In this case it seems that the positions of ascospores 6 and 7 were probably exchanged in the ascus. The data from this ascus indicates that segregation for pathogenicity occurred in the first nuclear division in the ascus and segregation for mating type occurred in the second nuclear division due to crossing over between this locus and the centromere in the first division. Data from other asci indicated that segregation of factors for pathogenicity and mating type occurred indipendently in either the first or second nuclear division and recombinant (nonparental) genotypes for pathogenicity were occasionally observed.

\section{Discussion}

It is generally considered that hybridization is an important means of pathogenic variation in fungi having a sexual stage as part of their life cycle. In Pyricularia, however, it may be premature to assume that the hybridization is a main factor for it, because the perfect stage has not been found in nature yet. In fact many instances of variation in pathogenicity have been reported in its asexual stage and mostly attributed to mutation, heterokariosis, or parasexual recombination. However, it appears that the experimental evidence is not always adequate to explain the controversial problems. The diversity of explanations attempted to account for the pathogenic variation seems to be indicative of the dificulty of identifying the factor(s) for pathogenicity without genetic analysis through the sexual stage. The knowledge obtained from the hybridization tests could serve as valuable information for conducting genetic studies for pathogenicity in the asexual stage as well as in the sexual stage. Therefore, the first attempt was made to demonstrate experimentally the genetic segregation for pathogenicity through the sexual stage of this organism.

According to the cytological study of the ascus ${ }^{17)}$, three successive nuclear divisions in the ascus result in the formation of eight nuclei around which ascospores are delimited, $i$. $e$., the eight ascospores in each ascus originate from the one-celled young ascus containing the same cytoplasm with a diploid nucleus. Therefore, if the factors for pathogenicity and mating type are of cytoplasmic origin, the phenotypes of the eight ascospores in the ascus should be all the same. Since the tetrad analysis indicated the segregation of factors in the ascus, it appears that factors for pathogenicity and mating type are of chromosomal origin. However, the possibility cannot be eliminated completely that extra-chromosomal factors are involved in pathogenicity, because of the limited number of isolates used.

Data of the hybridization tests suggest that pathogenicity to weeping lovegrass or finger millet is conditioned by a single gene, and the pathogenicity to each of these hosts seems to be controlled by different genes located at different loci on homologous chromosomes. Although additional gene(s) for pathogenicity will un- 
doubtedly be detected by increasing the number of differential hosts and isolates used, it remains for further study to identify the gene(s) conditioning pathogenicity to various hosts including rice. Pathogenicity and mating type were inherited independently, which made it possible to cross various types of isolates. Therefore, if hybridization really occurred in nature, it could play an important role in developing new types of isolates having diverse pathogenicity.

Greatful appreciation is expressed to Professor T. T. Hebert, North Carolina State University, for reviewing the manuscript, and to Dr. Hozumi Suzuki, Tohoku National Agricultural Experiment Station, for his helpful advice. The aouthor is indebted to Drs. N. Nishihara and K. Isawa (National Grassland Research Institute) and K. Ohyama and H. Sato (Kyushu National Agricultural Experiment Station), for providing fungus cultures and seeds of test plants.

\section{Literature cited}

1. Fatemi, J. and Nelson, R. R. (1977). Phytopathology $67: 1523-1525$.

2. Frederiksen, R. A. (1975). Proceedings of the seminar on horizontal resistance to the blast disease of rice, CIAT, Cali, Colombia. pp. 155-160.

3. Genovesi, A. D. and Magill, C. W. (1976). Can. J. Microbiol. $22: 531-536$.

4. Giatgong, P. and Frederiksen, R. A. (1969). Phytopathology $59: 1152-1157$.

5. Hebert, T. T. (1971). Phytopathology $61: 83-87$.

6. Hebert, T. T. (1975). Proceedings of the seminar on horizontal resistance to the blast disease of rice, CIAT, Cali, Colombia. pp. 161-164.

7. Kato, H., Yamaguchi, T. and Nishihara, N. (1976). Ann. Phytopath. Soc. Japan 42: 507-510.

8. Kuribayashi, K. (1953). Ibid. $18: 73$ (Abstr.).

9. Ou, S. H. and Ayad, M. R. (1968). Phytopathology $58: 179-182$.

10. Suzuki, H. (1965). The Rice Blast Disease. John Hopkins Press, Baltimore. pp. 111-149.

11. Suzuki, H. (1967). Studies on biologic specialization in Pyricularia oryzae Cav., Tokyo Univ. Agr. and Tech. pp. 235.

12. Ueyama, A. and Tsuda, M. (1975). Trans. Mycol. Soc. Japan $16: 420-422$.

13. Yaegashi, H. and Nishihara, N. (1976). Ann. Phytopath. Soc. Japan $42: 511-515$.

14. Yaegashi, H. (1977). Ibid. $43: 432-439$.

15. Yaegashi, H. and Udagawa, S. (1978). Can. J. Bot. $56: 180-183$.

16. Yaegashi, H. and Hebert, T. T. (1976). Ann. Phytopath. Soc. Japan $42: 556-562$.

17. Yaegashi, H. and Hebert, T. T. (1976). Phytopathology $66: 122-126$.

18. Yamasaki, Y. and Niiseki, H. (1965). Bull. Nat. Inst. Agr. Sci., D. 13 : 231-274.

和 文 摘 要

$$
\begin{gathered}
\text { ウィピングラブグラスとシコクビエから分離した } \\
\text { いもち病菌の交配による病原性の遺伝 }
\end{gathered}
$$

$$
\text { 八重樫博志 }
$$

いもち病菌の病原性ならびに交配型の遺伝様式を解明するため, 完全世代の利用を試みた。実験には, 完 全世代を良く形成するウィピングラブグラスから分離した菌株（以下ウィピングラブグラス菌）上シコクビ エから分離した菌株（以下シコクビエ菌）上を供試した。ウィピングラブグラス菌(あるいはシコクビエ菌） 同士の交配からは交配親株と同じ病原性のあのだけが得られたが，病原性を異にするウィピングラブグラス 菌とシコクビエ菌との交配では病原性の分離が確認された。すなわち，両菌株の交配によって得られた子の う胞子（計325）には，ウィピングラブグラスにのみ病原性を示すむの（136）,シコクビエにのみ病原性を示 すもの（127）, 両方に病原性を示すむの（26）, 両方浪原性を示さないもの（36）が認められた。ウィピン 
グラブグラス（あるいはシコクビエ）に病原性を示すあのと示さないあのの比率がほぼ 1 ： 1 であった事か ら, これら答主に対する病原性はそれぞれ一個の異なる遺伝子によって支配されているものと推察される。 また，非交又型のものが圧倒的に多く分離された事，一部交又型のものも得られた事から，これら二つの遺 伝子は相同染色体上の異なる座に位置しているものと推察される。交配型はてれら病原性とは独立に遺伝し た。これら病原性，交配型を支配している遺伝子が染色体上に位置しているという推定は，同一子のう内の 8 個の子のう胞子を検定した結果からも確められた。 